\title{
43. CONSOLIDATION, TRIAXIAL SHEAR-STRENGTH, AND INDEX-PROPERTY CHARACTERISTICS OF ORGANIC-RICH SEDIMENT FROM THE PERU CONTINENTAL MARGIN: RESULTS FROM LEG $112^{1}$
}

\author{
Homa J. Lee, ${ }^{2}$ Robert E. Kayen, ${ }^{2}$ and William G. McArthur ${ }^{2}$
}

\begin{abstract}
Sites 679, 680, and 681 of the Ocean Drilling Program were drilled along an east-west transect across an organic-rich, diatomaceous, coastal upwelling facies that occurs as a shelf/slope lens along the Peru continental margin. Seven $60-\mathrm{cm}$-long, unsplit core sections from these sites were tested for consolidation, triaxial shear strength, and geotechnical index properties. The testing showed that the sediment has unusually high water content, Atterberg limits, degree of overconsolidation, compressibility, and shear strength. The sediment has unusually low density and grain specific gravity. Atterberg limits, grain specific gravity, compressibility, and apparent excess maximum past stress increase linearly with organic-carbon content, which also correlates positively with diatom content. Overconsolidation measured in these tests is probably not a result of sediment erosion or slumping, but rather the result of diagenesis or interparticle bonding by organic matter. High shear strengths were measured throughout, but particularly high relative shear strengths (as indicated by friction angles and degrees of dilatancy during shear) occur near 20 mbsf. This "crustlike" behavior is probably produced by early diagenesis (perhaps including dolotomization) within the upper $20 \mathrm{~m}$, and is complemented by interlocking of diatoms.
\end{abstract}

\section{INTRODUCTION}

A distinctive, organic-rich, diatomaceous, coastal upwelling facies occurs as a shelf/slope lens along the Peru continental margin (Reimers and Suess, 1983). Previous investigations of Reineck box cores and Kasten cores recovered within this facies disclosed unique physical properties (Busch and Keller, 1981, 1982, 1983; Keller, 1982, 1983). Specifically, if the organic-carbon content is high, the sediment displays particularly high water content, plasticity, compressibility, and rate of secondary compression. Such high values of these properties have been reported for organic-rich sediment elsewhere, and correlations of some of these properties with organic-carbon content have been developed (Booth and Dahl, 1986).

These previous studies of the upwelling facies off Peru also disclosed high shear strengths and apparent maximum past consolidation stresses. For example, when testing one core (Core $41 \mathrm{~K}$, location shown in Fig. 1) from the central part of the organic-rich sediment lens, Busch and Keller (1981) obtained vane shear strengths of about $3 \mathrm{kPa}$ near the seafloor surface; these strengths increased roughly linearly with depth to more than $20 \mathrm{kPa}$ at the base of the core $(2 \mathrm{~m})$. This surface strength is not unusual, but these strengths at depth and the rate of increase in strength with increasing overburden stress are much higher than one would expect in cohesive marine sediment (Keller, 1969; Busch and Keller, 1981). Within this same core, apparent maximum past stresses $\left(\sigma_{v m}{ }^{\prime}\right)$ were determined from the results of standard consolidation tests using Casagrande's technique (1936). In the absence of interparticle bonding or other complicating factors, the estimated apparent maximum past stress should equal the greatest overburden stress ever exerted on the sediment sample. If the apparent maximum past stress differed from today's overburden effective stress $\left(\sigma_{v}{ }^{\prime}\right.$, estimated assuming no excess pore-

\footnotetext{
${ }^{1}$ Suess, E., von Huene, R., et al., 1990. Proc. ODP, Sci. Results, 112: College Station, TX (Ocean Drilling Program).

2 U.S. Geological Survey, Menlo Park, CA 94025.
}

water pressure), the difference could be attributed to removal of overburden, perhaps by erosion or slumping. With nearsurface marine sediment, a difference often exists between $\sigma_{v m}{ }^{\prime}$ and $\sigma_{v}{ }^{\prime}$ that cannot be explained by simple sediment removal and is probably related to interparticle bonding or early diagenesis (Richards and Hamilton, 1967). A high degree of such "apparent overconsolidation" was observed by Busch and Keller (1982) when testing sediment from the organic-rich sediment lens. The apparent overconsolidation ratio $\left(\sigma_{v m}{ }^{\prime} / \sigma_{v}{ }^{\prime}\right)$ ranged between 7 and 17. Busch and Keller $(1981,1982)$ suggested that the high degree of apparent overconsolidation, as well as the high shear strengths at depth in the cores, was related to interparticle bonding of sediment particles by organic substances. Such bonding may indeed be the cause of these unusual strength and consolidation characteristics, but the relationship is not a simple one. For example, the organiccarbon content of the core tested by Busch and Keller is highest (greater than $16 \%$ ) within the upper few centimeters and decreases steadily with depth to values of less than $4 \%$ at the base of core. Thus, the highest strengths occur in the sediment with the lowest organic-carbon content.

Other investigators (Andersland et al., 1981; Pusch, 1973; and Rashid and Brown, 1975) also evaluated the influence of organic matter on sediment shear strength. In these studies, shear strength typically increased with increasing organiccarbon content when the organic-carbon content was greater than about $2 \%$, but the experiments considered only artificially prepared specimens in which organic matter was mixed in with other sedimentary constituents. Accordingly, the measured shear strengths represent remolded values, and the applicability of the studies to actual field conditions is questionable. Neither the influence of in-situ overburden stress nor the influence of sediment age on strength properties was determined.

Busch and Keller's $(1981,1982,1983)$ tests were conducted on natural sediment samples and were not subject to the problems associated with artificial specimen preparation. However, the shortness of the tested core samples (lengths up to $4.74 \mathrm{~m}$ ) limits the applicability of the findings with regard to the effects of age and overburden stress on strength. Their 


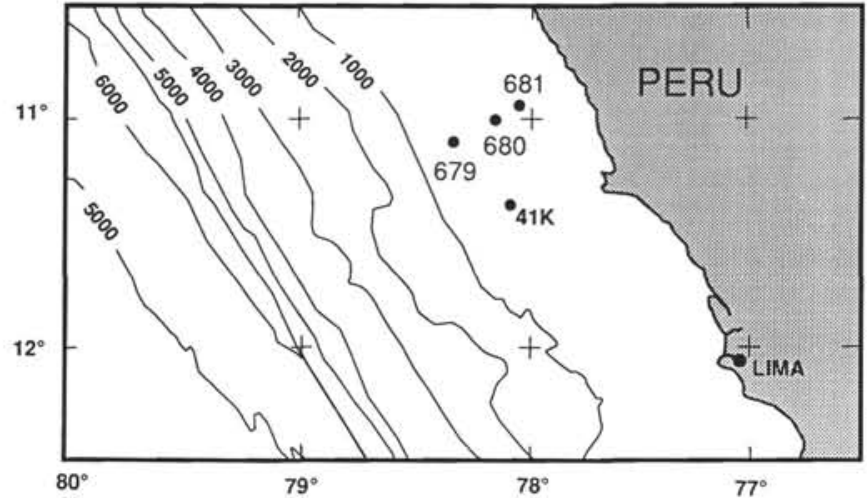

Figure 1. Locations of Sites 679,680 , and 681 . Also shown is the location of Core $41 \mathrm{~K}$, which was tested by Busch and Keller (1981, 1982, 1983). Isobaths shown in meters.

studies showed that variations of shear strength, apparent maximum past stress, and organic-carbon content with depth in the sediment column were all significant and imply that a complex relationship exists between organic material and geotechnical properties. Testing sediment that has been buried more deeply than that tested by Busch and Keller can better define this complex relationship and identify the causes of the variations.

During Leg 112, whole-round subsamples from three sites $(679,680$, and 681 , locations shown in Fig. 1) were preserved for laboratory testing onshore to determine geotechnical properties. The three sites were drilled as part of an east-west transect at approximately $11^{\circ} \mathrm{S}$ (Suess, von Huene, et al., 1988) and represent water depths ranging from $151 \mathrm{~m}$ at Site 681 to $450 \mathrm{~m}$ at Site 679 . Since the beginning of the Quaternary period, these sites have experienced strong coastal upwelling; the stratigraphic record is relatively continuous, well preserved, and contains only minor amounts of terrigenous detritus (Suess, von Huene, et al., 1988). Within the upper 75 mbsf, from which the whole-round subsamples were obtained, the sediment consists predominantly of diatomaceous mud with varying amounts of foraminifers and terrigenous sediment. Organic-carbon contents vary from $1 \%$ to $9 \%$ within the whole-round subsamples and show cyclic variations downhole. The dominant reaction mechanism observed in the sediment is decomposition of organic matter by anaerobic microbial processes, mainly by sulfate and carbonate reduction. Under these conditions, dolomite is formed as a diagenetic product following sulfate reduction (Baker and Burns, 1985). At Sites 679,680 , and 681 , dolomite rhombs begin to occur within the upper $1 \mathrm{mbsf}$. At greater depths, dolomite occurs as disseminated small rhombs in unlithified sediments, as small hard nodules, and as thin lithified beds (Suess, von Huene, et al., 1988).

The whole-round subsamples were acquired using the hydraulic piston corer and, in an engineering sense, are most likely relatively undisturbed. All samples were recovered within the organic- and diatom-rich upwelling facies. Consolidation and triaxial tests were conducted to understand the strength and stress history characteristics of the sediment. In addition, other index properties (water content, grain density, Atterberg limits, and organic-carbon content) were measured to allow us to correlate measurements for comparison with other studies. This study summarizes these test results, which greatly extend the sub-bottom depth range over which the interrelationship between geotechnical behavior and organiccarbon content can be defined for this facies.

\section{METHODS}

\section{Subsamples}

Seven 60-cm-long, 7-cm-diameter unsplit sections (three each from Holes $679 \mathrm{C}$ and $681 \mathrm{C}$ and one from Hole 680C) were preserved and stored under refrigeration. Each section was subsampled to yield specimens for one constant-rateof-strain consolidation test, at least four triaxial strength tests, and various index property tests.

\section{Index Properties}

Organic-carbon content was calculated as the difference between the total carbon and inorganic-carbon content. All carbon content analyses were conducted using a Coulometrics Inc. $\mathrm{CO}_{2}$ coulometer. ${ }^{3}$ Grain specific gravity $\left(G_{r}\right)$ was determined using an air comparison pycnometer. The liquid limit $(L L)$, plastic limit $(P L)$, and plasticity index $(P I)$ were measured following ASTM standards (American Society for Testing and Materials, 1982). Liquid and plastic limits are water contents at the upper and lower boundaries, respectively, of the range in which a sediment deforms as a plastic material. The difference between these two limits is the plasticity index.

\section{Consolidation Properties}

In an engineering sense, consolidation is the process of expelling pore water under the influence of confining stresses applied to sediment. In a one-dimensional consolidation test, a wafer of sediment is constrained laterally and subjected to increasing axial loads. Changes in void ratio (volume of voids/volume of solids, related directly to porosity), which result from the increased loads, are monitored as a function of time and axial load. Results are presented as plots of void ratio vs. effective stress, where effective stress is the total stress applied axially minus the pore water pressure. In the standard consolidation test (Lambe, 1951), axial loads are applied incrementally and allowed to remain in place until increased pore-water pressures associated with the application of each load increment are able to dissipate. Each load increment generates one point on a void ratio-effective stress plot. Such tests can consume a great deal of time, often many weeks. Here, consolidation testing was performed using the constantrate-of-strain technique (Wissa et al., 1971) in which axial loads are applied steadily to make the compression rate of the sediment wafer constant. By measuring axial load, pore water pressure, and axial strain, the effective stress and void ratio can be calculated at any point during the test, and a continuous plot of void ratio vs. effective stress can be obtained. Such a test can typically be performed in a day or less.

Consolidation tests are frequently used to estimate previous stress history. A sediment that has been preloaded in the field to a particular stress level retains a memory of that stress. When a sample of that sediment is taken and reloaded in a consolidation test, the sediment displays incompressibility at stresses below its previous maximum past stress. When stresses beyond previous maximum past stress are reached, compressibility increases significantly. Casagrande's construction (1936) is a standardized means of identifying where compressibilities change; that is, the greatest effective stress that the sediment apparently experienced in the field. If the present overburden effective stress $\left(\sigma_{v}{ }^{\prime}\right.$, typically estimated by integrating the submerged sediment density with respect to depth below the seafloor) roughly equals the maximum past stress $\left(\sigma_{v m}{ }^{\prime}\right)$, the sediment is considered to be normally

\footnotetext{
${ }^{3}$ Any use of trade names is for descriptive purposes only and does not imply endorsement by the U.S. Geological Survey.
} 
Table 1. Index properties.

\begin{tabular}{lcccccc}
\hline Hole & $\begin{array}{c}\text { Depth } \\
\text { (mbsf) }\end{array}$ & $\begin{array}{c}\text { Organic } \\
\text { carbon } \\
\text { content }(\%)\end{array}$ & $\begin{array}{c}\text { Liquid } \\
\text { limit } \\
(\%)\end{array}$ & $\begin{array}{c}\text { Plastic } \\
\text { limit } \\
(\%)\end{array}$ & $\begin{array}{c}\text { Plasticity } \\
\text { index } \\
(\%)\end{array}$ & $G_{r}$ \\
\hline $679 \mathrm{C}$ & 23.9 & 6.61 & 232 & 151 & 81 & 2.25 \\
& 24.3 & 6.38 & - & - & - & 2.28 \\
& 50.7 & 3.06 & 136 & 87 & 49 & 2.36 \\
& 51.1 & 3.47 & - & - & - & 2.41 \\
& 72.8 & 6.39 & - & - & - & 2.36 \\
$680 \mathrm{C}$ & 73.2 & 4.98 & 189 & 106 & 83 & 2.48 \\
& 20.8 & 5.41 & 53 & 40 & 13 & 2.39 \\
$681 \mathrm{C}$ & 20.9 & 2.23 & - & - & - & 2.66 \\
& 11.4 & 1.75 & - & - & - & 2.80 \\
& 11.5 & 2.15 & 99 & 42 & 57 & - \\
& 11.8 & 1.59 & - & - & - & 2.73 \\
& 30.3 & 5.29 & - & - & - & 2.44 \\
& 30.5 & 5.29 & - & - & - & 2.46 \\
& 30.8 & 6.52 & 165 & 103 & 62 & - \\
& 70.0 & 1.09 & - & - & - & 2.78 \\
& 70.3 & 1.27 & 66 & 41 & 25 & - \\
\hline
\end{tabular}

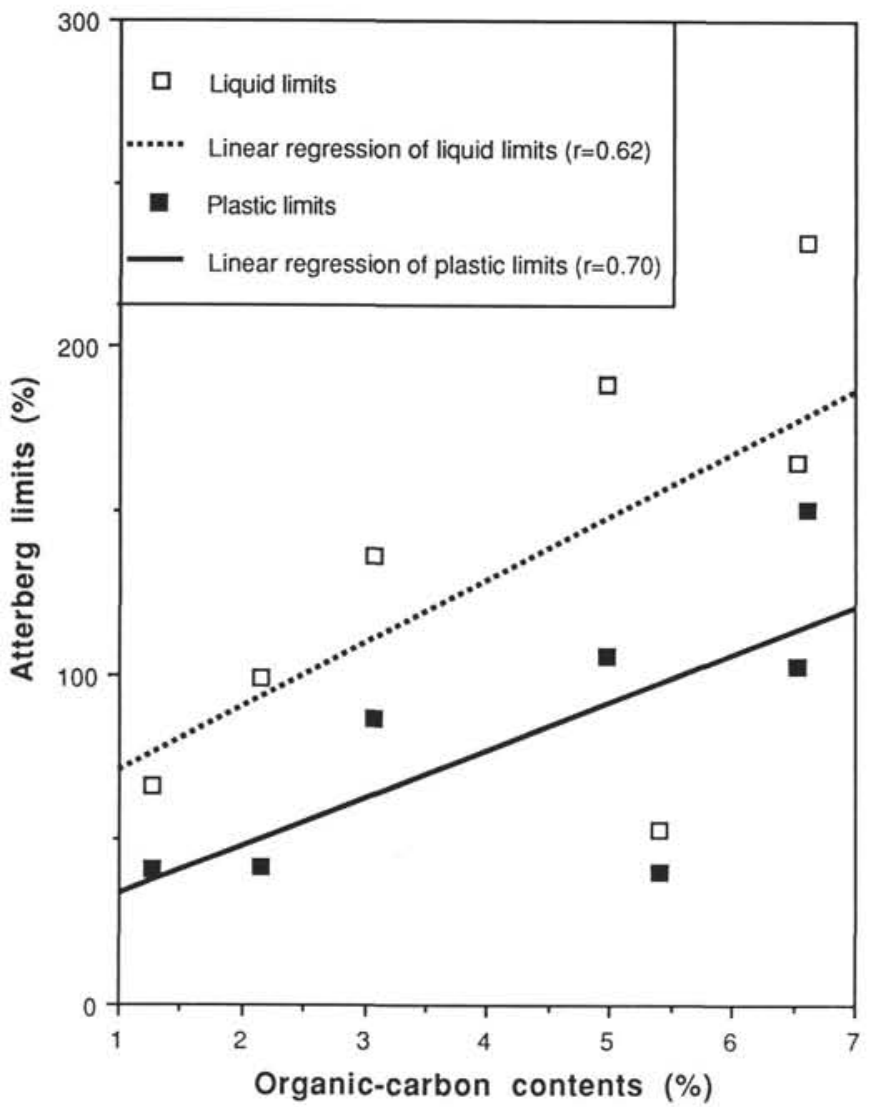

Figure 2. Correlation of Atterberg limits with the organic-carbon contents.

consolidated. If $\sigma_{v m}{ }^{\prime}$ exceeds $\sigma_{v}{ }^{\prime}$, the sediment is considered to be overconsolidated. The overconsolidation ratio $(O C R)$, $\sigma_{v m}{ }^{\prime} / \sigma_{v}{ }^{\prime}$, is one measure of the degree of overconsolidation, but differs near the seafloor surface as $\sigma_{v}{ }^{\prime}$ approaches zero and $O C R$ approaches infinity. Another measure of overconsolidation is the excess maximum past stress, $\sigma_{e}{ }^{\prime}$, which is equal to $\sigma_{v m}{ }^{\prime}-\sigma_{v}{ }^{\prime}$. Such a measure is preferable because it remains well defined, even for shallow burial. As discussed previously, interparticle bonding and other factors can cause a sediment to appear overconsolidated even though stresses greater than its present overburden were never experienced in the field. Apparent and true overconsolidation are difficult to separate using the results of consolidation tests.

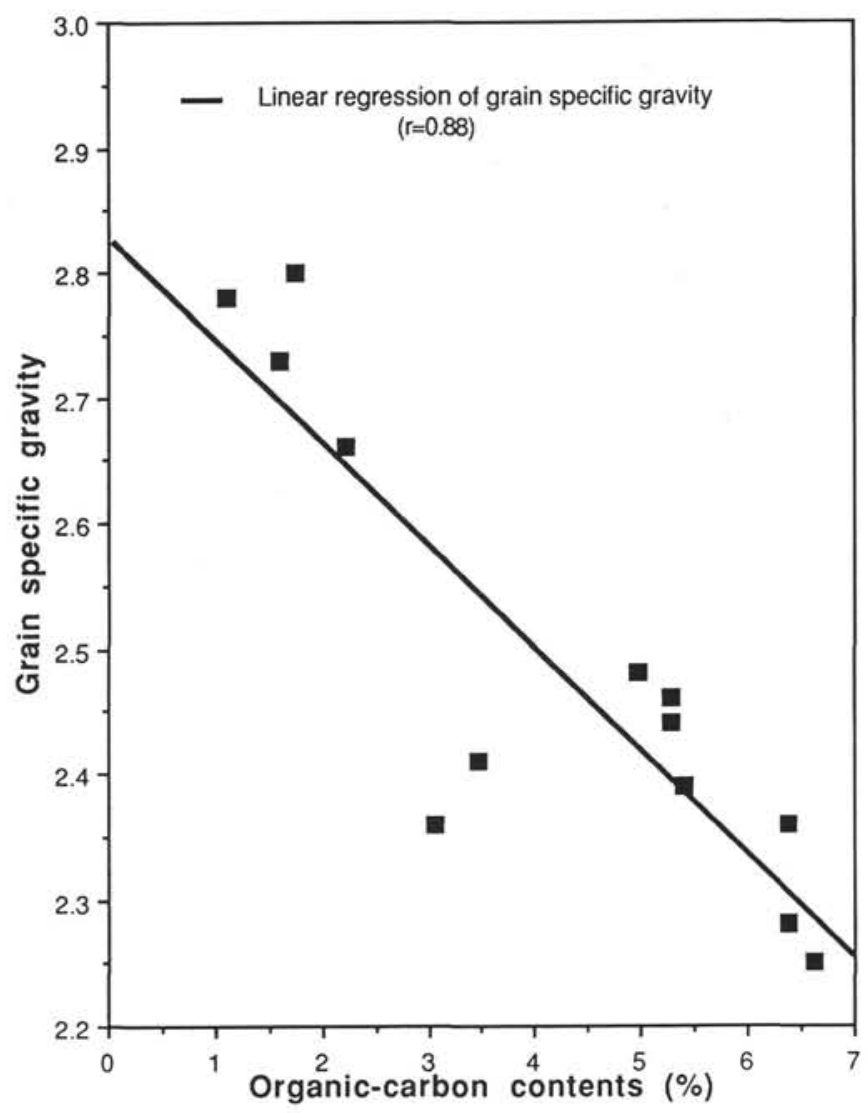

Figure 3. Correlation of grain specific gravity with organic-carbon contents.

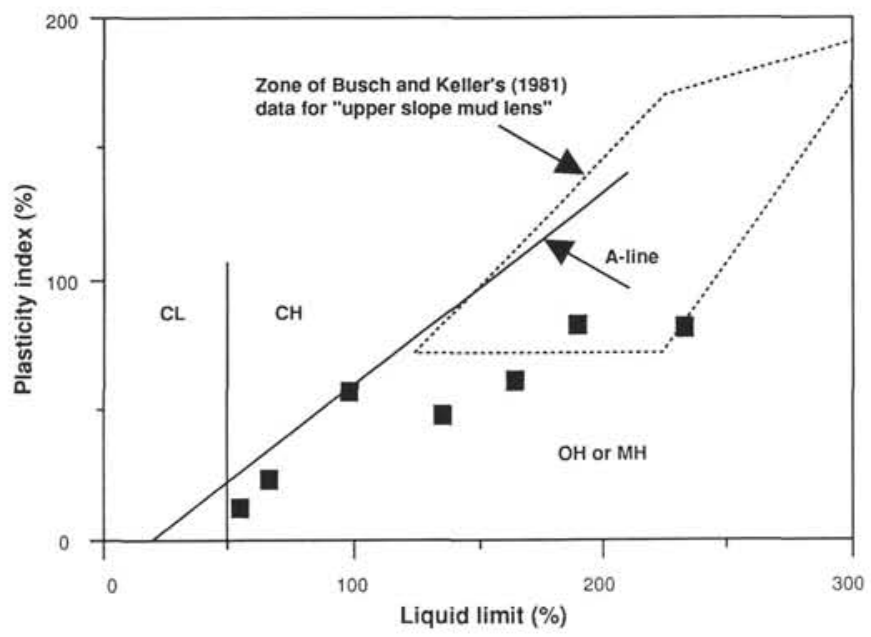

Figure 4. Plasticity chart indicating the classification of sediment tested from Site 679,680 , and $681(\mathrm{OH}=$ organic clay of mediumto-high plasticity, $\mathrm{MH}=$ inorganic silt, $\mathrm{CL}=$ inorganic clays of low-to-medium plasticity, $\mathrm{CH}=$ inorganic clays of high plasticity). A zone that defines the variation of data presented by Busch and Keller (1981) is shown for comparison.

\section{Triaxial Strength Properties}

A triaxial test provides a means of (1) changing the effective confining stress of a sediment sample and (2) measuring that sample's strength corresponding to that effective confining stress. In our triaxial testing program, cylindrical sam- 
Table 2. Consolidation test results.

\begin{tabular}{lccccccc}
\hline Hole & $\begin{array}{c}\text { Depth } \\
(\mathrm{mbsf})\end{array}$ & $\begin{array}{c}\text { Organic } \\
\text { carbon } \\
\text { content } \\
(\%)\end{array}$ & $\begin{array}{c}\text { Initial } \\
\text { water } \\
\text { content } \\
(\%)\end{array}$ & $\begin{array}{c}\text { Maximum } \\
\text { past stress } \\
\left(\sigma_{v m^{\prime}}, \mathrm{kPa}\right)\end{array}$ & $\begin{array}{c}\text { Overburden } \\
\text { effective stress } \\
\left(\sigma_{v^{\prime}}, \mathrm{kPa}\right)\end{array}$ & $\begin{array}{c}\text { Excess } \\
\text { maximum } \\
\text { past stress } \\
\left(\sigma_{e^{\prime}}, \mathrm{kPa}\right)\end{array}$ & $\begin{array}{c}\text { Compression } \\
\text { index }\left(C_{c}\right)\end{array}$ \\
\hline $679 \mathrm{C}$ & 24.4 & 7.67 & 197.4 & 300 & 52 & 248 & 2.07 \\
& 50.7 & 3.37 & 129.1 & 220 & 146 & 74 & 0.90 \\
& 50.7 & 3.14 & 127.1 & 210 & 146 & 64 & 1.05 \\
$680 \mathrm{C}$ & 72.7 & 6.55 & 159.9 & 400 & 225 & 175 & 1.63 \\
$681 \mathrm{C}$ & 21.0 & 3.22 & 48.7 & 300 & 70 & 230 & 0.38 \\
& 11.5 & 2.15 & 104.5 & 135 & 39 & 96 & 1.02 \\
& 30.6 & 6.52 & 164.3 & 250 & 121 & 129 & 1.69 \\
& 70.2 & 1.23 & 67.7 & 310 & 285 & 25 & 0.57 \\
\hline
\end{tabular}

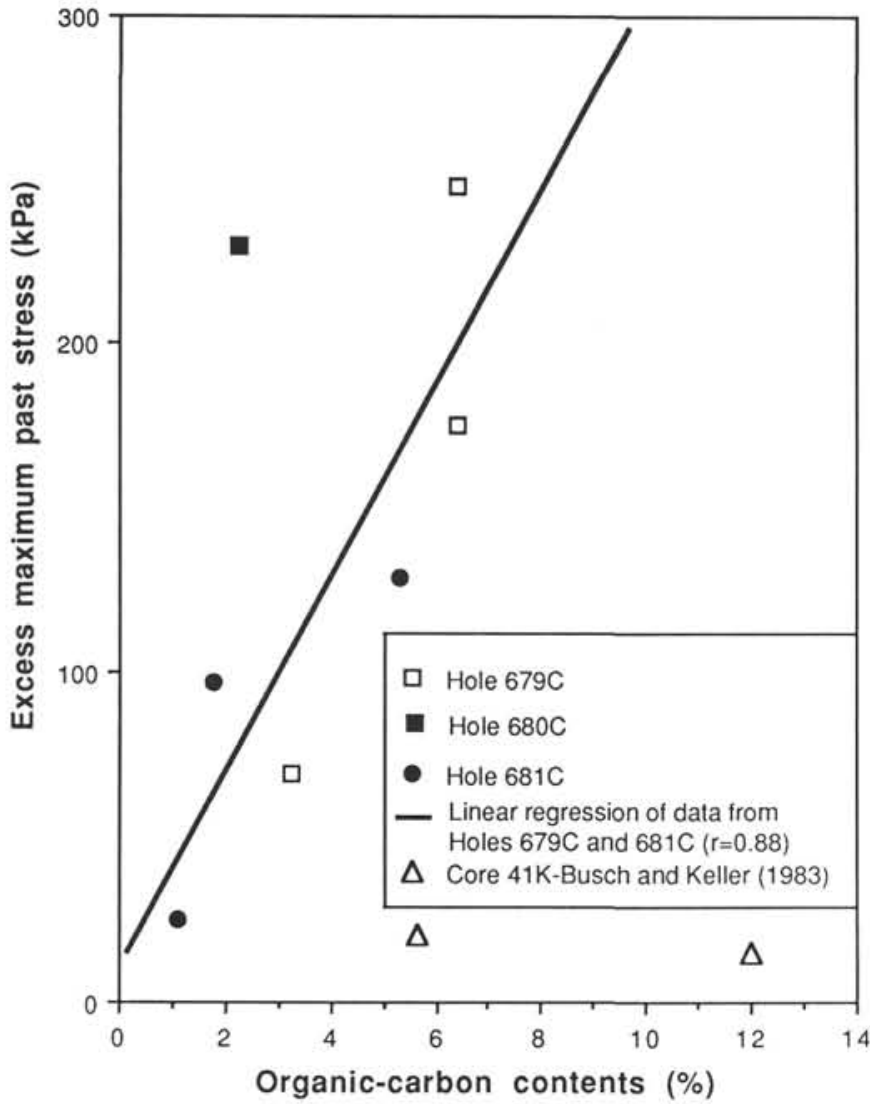

Figure 5. Correlation of excess maximum past stress $\left(\sigma_{e}{ }^{\prime}\right)$ with organic-carbon content. Regression line and correlation coefficient apply to Holes $679 \mathrm{C}$ and $681 \mathrm{C}$ only. Core $41 \mathrm{~K}$ was described by Busch and Keller (1982).

ples ( $3.5 \mathrm{~cm}$ diameter by $10 \mathrm{~cm}$ high) were enclosed in impervious membranes and placed in a triaxial cell in which the cell's confining pressure and sample pore water pressure could be varied independently. By establishing a differential between cell and pore pressures, the samples were forced to expel pore water and come to equilibrium with a predetermined effective confining stress. Drainage valves leading to the sample were then closed, and each sample was brought to shear failure under increasing axial load and a constant strain rate of about $3 \% / \mathrm{hr}$. The shear stress corresponding to the peak axial stress was taken as the undrained shear strength. These types of tests are termed isotropically consolidatedundrained triaxial compression tests. Pore water pressures were measured throughout the undrained loading stage so that all stresses could be expressed as effective stresses (effective

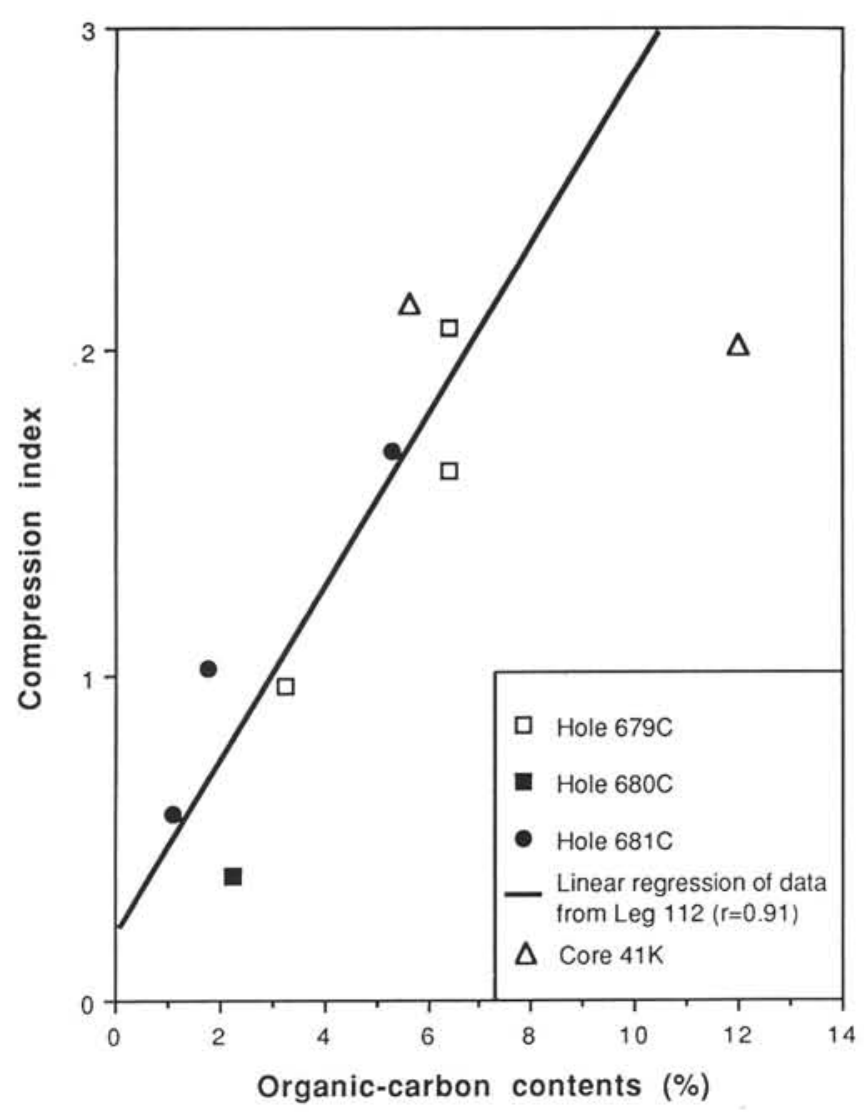

Figure 6. Correlation of compression index, $\mathrm{C}_{c^{\prime}}$, with organic-carbon contents. Regression line and correlation coefficient do not reflect Core $41 \mathrm{~K}$, described by Busch and Keller (1982).

stress $=$ total stress minus pore water pressure). A detailed description of triaxial testing was given by Bishop and Henkel (1957).

Four different types of triaxial tests were performed on sediment from each 60 -cm-long section preserved for this program. These tests differed according to the effective confining stress (consolidation stress) applied before undrained loading and shear failure. In Type 1 only a small effective confining stress was applied before undrained loading. This small consolidation stress equaled the residual effective stress retained by the sample, which was determined by measuring the residual negative pressure present in the sample pore water (Lee, 1979). These types of tests are valuable because they can define the sediment failure envelope at low stress levels, where the relative influence of interparticle bonding is most significant. 
Table 3. Triaxial test results.

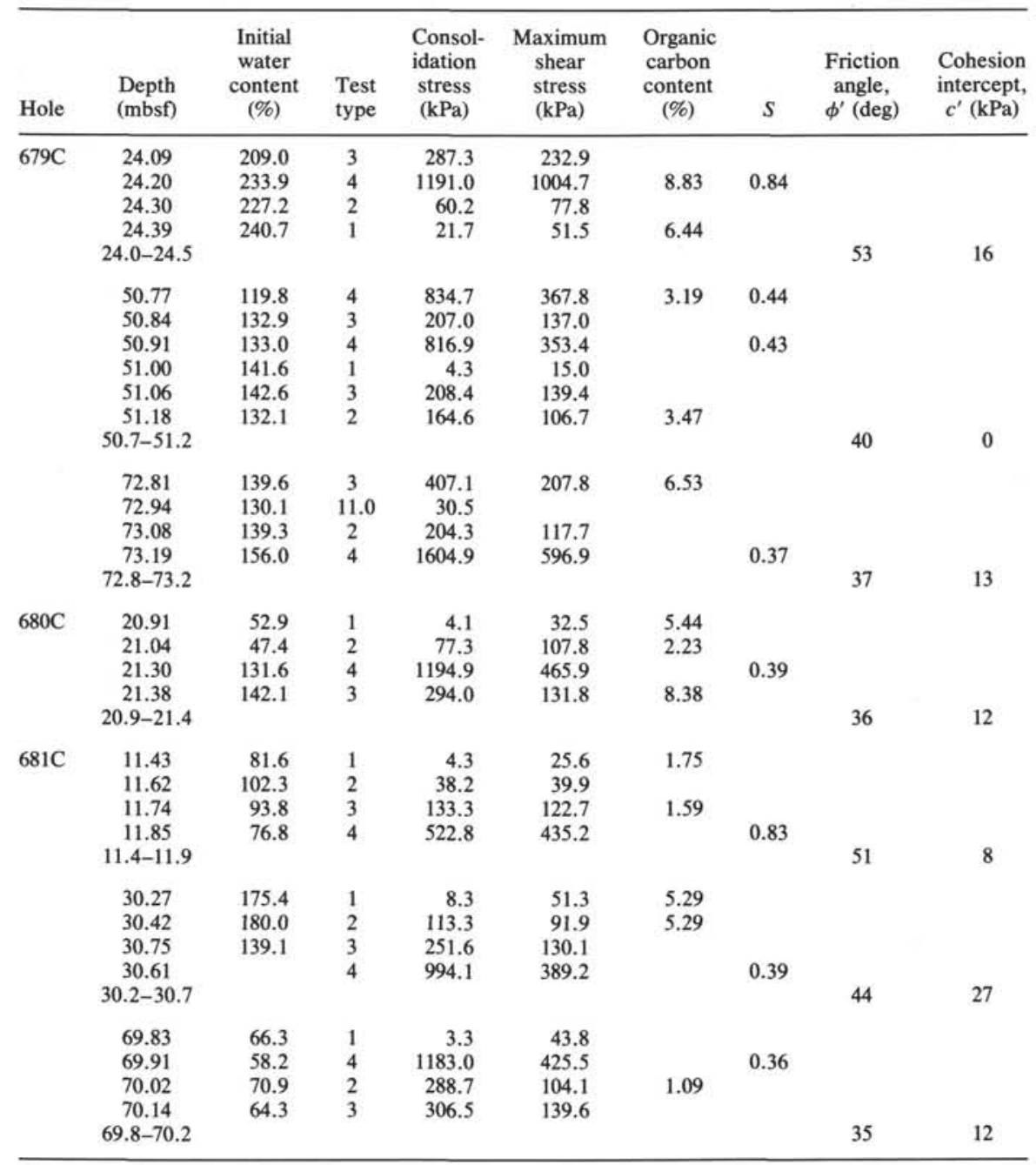

In Type 2, the samples were consolidated under an isotropic effective confining stress equal to the in-situ overburden effective stress. That is, the sample was returned to almost the same effective stress conditions inherent before it was withdrawn from the seafloor. In Type 3, the sample was consolidated to the maximum past stress, determined by an adjacent consolidation test. Both the second and third test types provide information about the sediment failure envelope under intermediate effective stress conditions.

In Type 4, the samples were consolidated isotropically to about four times the maximum past stress. Ladd and Foott (1974) specified that consolidation to such high stress levels often produces a specimen that behaves the way a normally consolidated sediment element behaves in the field. For normally consolidated sediment, the ratio of the undrained shear strength to the effective consolidation stress is a constant, $S$. Thus, these tests allowed us to estimate $S$ and also to define the sediment failure envelope at high stresses. All four test types were used to develop a single Mohr-Coulomb failure envelope for each of the $60-\mathrm{cm}$ sections tested for this study. Each envelope is defined by its slope, the friction angle, $\phi^{\prime}$, and its intercept, the cohesion, $c^{\prime}$.

The effects of coring disturbance cause most strength measurements performed on sediment samples to differ from the in-situ shear strength of the sediment. One way to estimate the in-situ shear strength from the results of tests on core samples is to apply the SHANSEP (Stress History And Normalized Soil Engineering Properties) method of Ladd and Foott (1974). According to this method, the in-situ shear strength can be approximated by:

$$
s_{u}=\sigma_{v}{ }^{\prime} S(O C R)^{m},
$$

in which $s_{u}$ is the estimated in-situ undrained shear strength, $\sigma_{v}{ }^{\prime}$ is the in-situ overburden effective stress, $S$ is the ratio of shear strength to consolidation stress for normal consolidation, $O C R$ is the overconsolidation ratio, and $m$ is a sediment parameter typically equal to about 0.8 , although values can range from 0.2 to 1.0 (Ladd et al., 1977; Mayne, 1980). In our testing program, $S$ and $O C R$ values were measured for each of the seven $60-\mathrm{cm}$ core sections. The overburden stress, $\sigma_{v}{ }^{\prime}$, was calculated from shipboard density distribution measurements obtained at adjacent holes at the same site. The parameter, $m$, was assumed to equal 0.8 . Thus, an estimated undisturbed shear strength could be obtained for each of the sediment sections and compared with other estimates of strength from triaxial testing and also shipboard vane shear strengths measured at adjacent holes at the same site.

\section{RESULTS AND CORRELATIONS}

Within six of the seven 60 -cm-long unsplit sections tested for geotechnical properties, there was little lithologic variabil- 


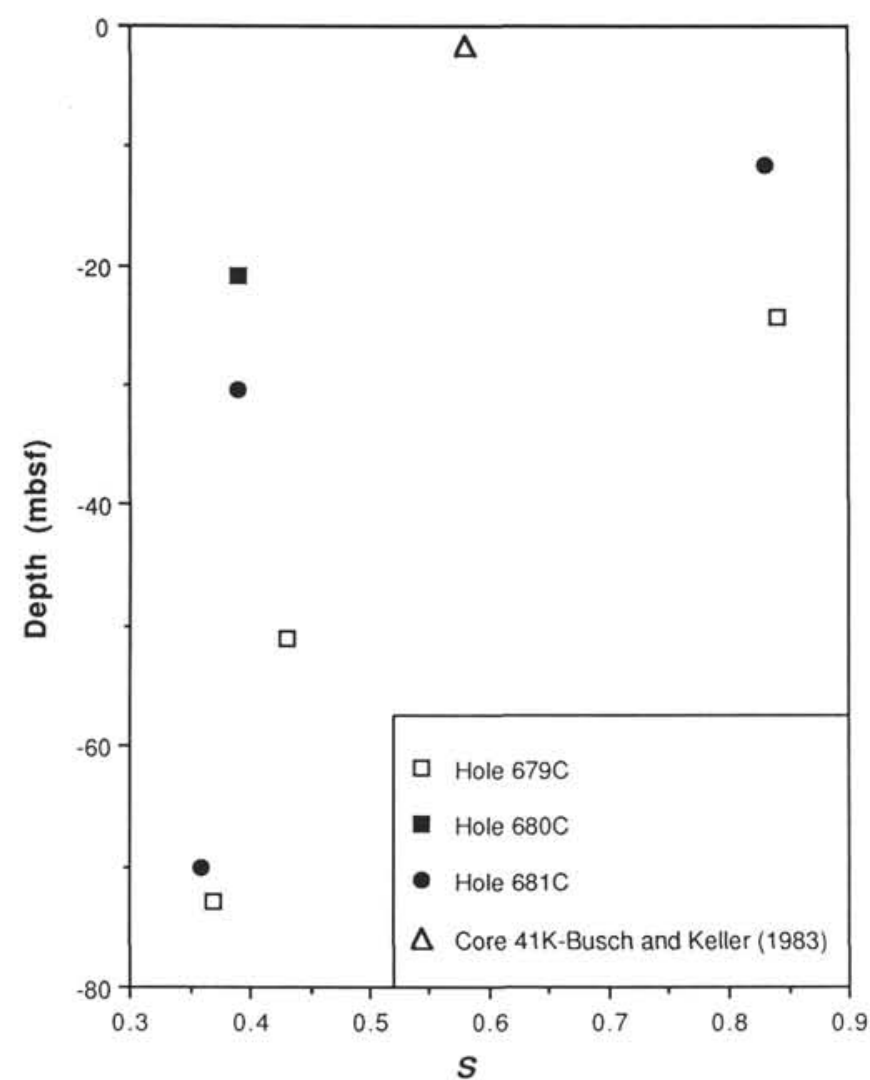

Figure 7. Variation of $S$, the ratio of triaxial shear strength to consolidation stress for normal consolidation with burial depth.

ity, although there is significant variability from section to section. Within the one section tested from Site 680 , there was significant variability, as indicated by organic-carbon contents ranging from $2 \%$ to $8 \%$, within the section itself.

\section{Index Properties}

Table 1 shows how index properties vary with organiccarbon content. Although data are scattered, a roughly linear relationship occurs between the organic-carbon content and Atterberg limits (Fig. 2) and the grain specific gravity (Fig. 3). Sensitivity of the Atterberg limits to changes in organiccarbon content is high, with the liquid limit increasing an average of $34 \%$, the plastic limit, $21 \%$, and the plasticity index, $13 \%$, for a $1 \%$ increase in organic carbon. The bulk grain specific gravity decreases about 0.1 for a $1 \%$ increase in organic-carbon content.

On a plasticity chart (PI vs. liquid limit, Fig. 4), the test results all fall below the A-line (Casagrande, 1948) in the zone that has the engineering classification of organic clays of high compressibility ( $\mathrm{OH}$, Fig. 4). Data points fall progressively farther from the A-line with increasing liquid limit.

\section{Consolidation Tests}

Each of the seven consolidation tests showed that the sediment was overconsolidated, with the excess maximum past stress ( $\sigma_{e}{ }^{\prime}$, maximum past stress minus present overburden effective stress) ranging from 25 to $250 \mathrm{kPa}$ (Table 2). If this overconsolidation resulted from removal of previous overburden, these levels of overconsolidation should indicate that the thickness of material removed ranged from 5 to as much as $80 \mathrm{~m}$. Most of these levels of overconsolidation are significantly higher than those observed by Busch and Keller
(1982) for the upper $1.4 \mathrm{~m}$ of the organic-rich facies $\left(\sigma_{e}{ }^{\prime}=15\right.$ to $20 \mathrm{kPa}$ ). With the exception of one consolidation test performed on sediment from Hole $680 \mathrm{C}$, the values of excess maximum past stress from Leg 112 correlate well (correlation coefficient of 0.88 ) with organic-carbon content (Fig. 5). Such a correlation might indicate that the apparent maximum past stresses were caused by interparticle organic bonding or by some other diagenetic process associated with organic-carbon content, for example, dolomitization. The high apparent maximum past stresses could also relate to interlocking of diatom frustules, given that high organic-carbon content sediment is also high in diatom content. Note that Busch and Keller's (1982) measured maximum past stresses lie well below the Leg 112 data points, suggesting that the correlation shown in Figure 5 applies only to sediment buried at least $20 \mathrm{~m}$ or more and does not apply to the seafloor surface. Excluding the near-seafloor surface, excess maximum past stresses do not increase consistently with depth downhole (Table 2), as would be expected if erosion or slumping in this slope environment caused the high excess maximum past stresses.

The compression index $\left(C_{c}\right.$, change in void ratio with change in the log of vertical effective stress) also correlates well with the organic-carbon content (Fig. 6). A good correlation was also reported by Busch and Keller (1982) for the same organic-rich facies. However, one sample tested from Core $41 \mathrm{~K}$ (Busch and Keller, 1982) does not follow the same trend as the data from Leg 112 (Fig.6).

\section{Triaxial Strength Properties}

The triaxial test program (Table 3) was designed to yield the Mohr-Coulomb failure envelope parameters, $\phi^{\prime}$ and $c^{\prime}$, as well as the ratio of shear strength to consolidation stress for normal consolidation, $S$. Also, the results of test Types 1 and 2 provide estimates of the in-situ shear strength. Test Type 1 yields a lower bound strength because it does not correct for the disturbance caused by sampling. Test Type 2 probably yields a strength that is slightly higher than the in-situ value because disturbance leads to a lower water content upon reconsolidation (Lambe and Whitman, 1969, p. 451).

The parameter, $S$, was obtained from Type 4 tests, where large initial consolidation stresses were applied to the samples before undrained shear. The obtained values of $S$ ranged from 0.36 to 0.84 ; these values are fairly high relative to values typically reported $(0.2$ to 0.75 , Lambe and Whitman, 1969 , p. 452). These values did not correlate with organic-carbon content (regression coefficient, $r$, of only 0.05 ), but instead varied with respect to sub-bottom depth (Fig. 7). The highest values (greater than 0.8 ) were obtained at $11 \mathrm{~m}$ in Hole $681 \mathrm{C}$ and at $24 \mathrm{~m}$ in Hole 679C. At greater sub-bottom depths, $S$ decreased to values of about 0.35 . No samples from depths shallower than $11 \mathrm{~m}$ were tested in our program, but Busch and Keller (1983) reported $S$ values equal to 0.58 for a nearby short core $(41 \mathrm{~K})$ within the same organic-rich facies.

The Mohr-Coulomb parameters, $\phi^{\prime}$ and $c^{\prime}$, were obtained from triaxial test results within a stress path framework (Figs. 8 through 10$)$. A stress path is a plot of shear stress $(q)$ vs. mean effective confining stress $\left(p^{\prime}\right)$ throughout the course of a triaxial test. An envelope that encloses all of the stress paths has a slope and an intercept that are directly related to $\phi^{\prime}$ and $c^{\prime}$ (Lambe and Whitman, 1969, p. 141). Stress paths also provide other information about sediment strength behavior; for example, stress paths that tend to the right show dilatancy during shear, whereas those that tend to the left indicate contraction. In Figures 8 through 10 , note the similar shapes of stress paths within each section and the different shapes between each section. In particular, note that these paths show a high degree of dilatancy for the shallowest section 

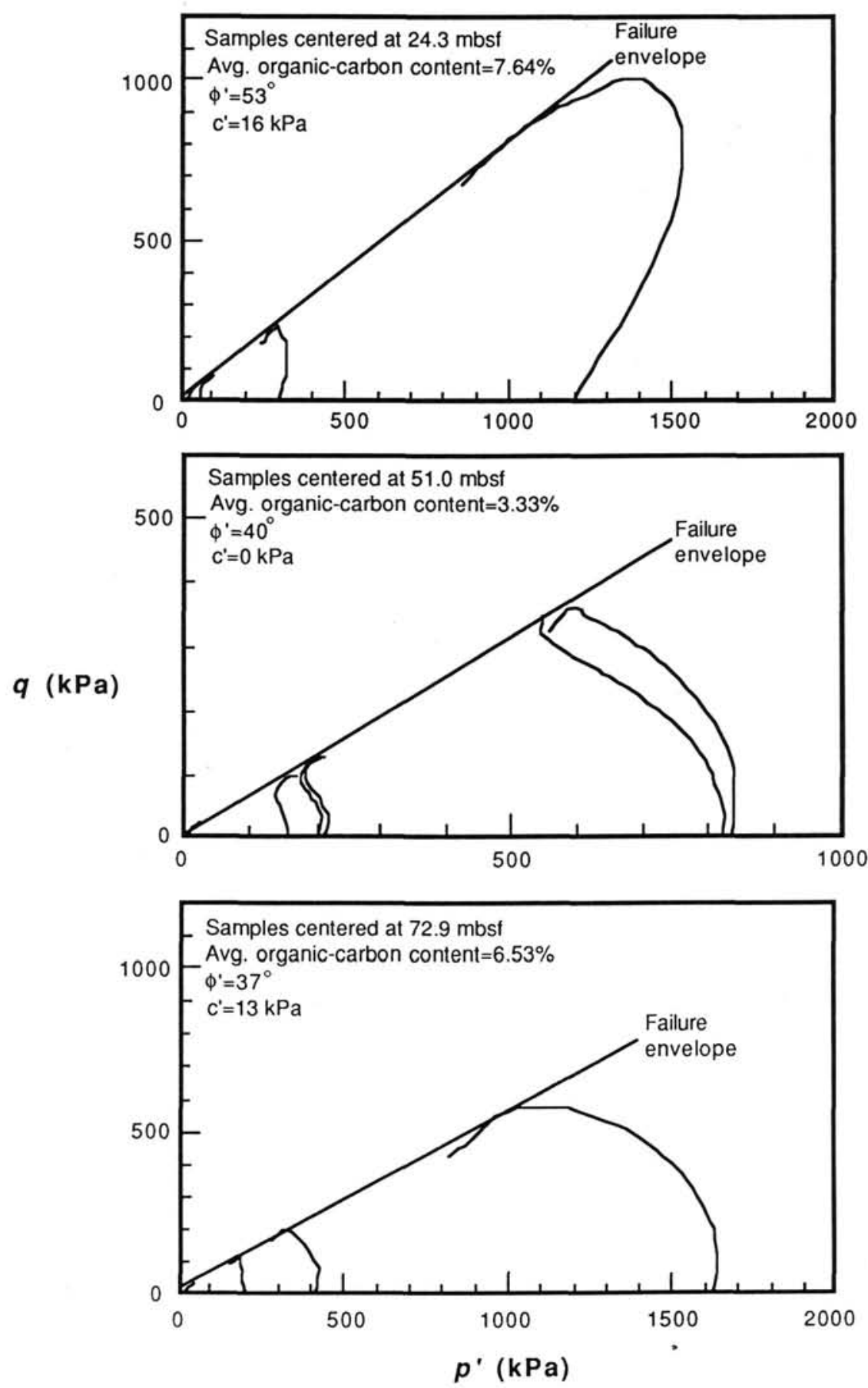

Figure 8. Stress paths (plots of shear stress, $q$, vs. normal effective confining stress, $p^{\prime}$ ) for Hole 679C. Path tendencies to the left indicate contractive sediment behavior; path tendencies to the right indicate dilative behavior. Failure envelopes shown were used to calculate values of friction angle, $\phi$, and cohesion intercept, $c^{\prime}$.

tested from Holes $679 \mathrm{C}$ and $681 \mathrm{C}$ and increasing degrees of contraction as sub-bottom depth increases.

The values of cohesion intercept, $c^{\prime}$ (Table 3) range from 8 to $27 \mathrm{kPa}$. These values are not particularly high and do not, in themselves, indicate a major influence of interparticle bonding. The friction angles, $\phi^{\prime}$, are greatest (more than $50^{\circ}$ ) at sub-bottom depths of $11 \mathrm{~m}$ in Hole $681 \mathrm{C}$ and $24 \mathrm{~m}$ in Hole $679 \mathrm{C}$, and decrease steadily to almost $30^{\circ}$ at $70 \mathrm{~m}$ (Fig. 11). Again, our program did not measure $\phi^{\prime}$ at depths shallower than $11 \mathrm{~m}$, but Busch and Keller (1983) reported a value of $44.2^{\circ}$ at $1.65 \mathrm{~m}$ in Core $41 \mathrm{~K}$. Including this value in our trend shows that $\phi^{\prime}$ rises to a peak value near $20 \mathrm{~m}$ and then decreases at greater depths. These values of friction angle are high in comparison with those generally measured for cohesive sediment (Lambe and Whitman, 1969, p. 307).

Multiplying values of $S$ (interpolated between measured data points in Fig. 7) by the overburden effective stress distribution for a given hole provides an estimate of what the shear-strength distribution would be were the sediment normally consolidated (Figs. 12 through 14). These figures show 


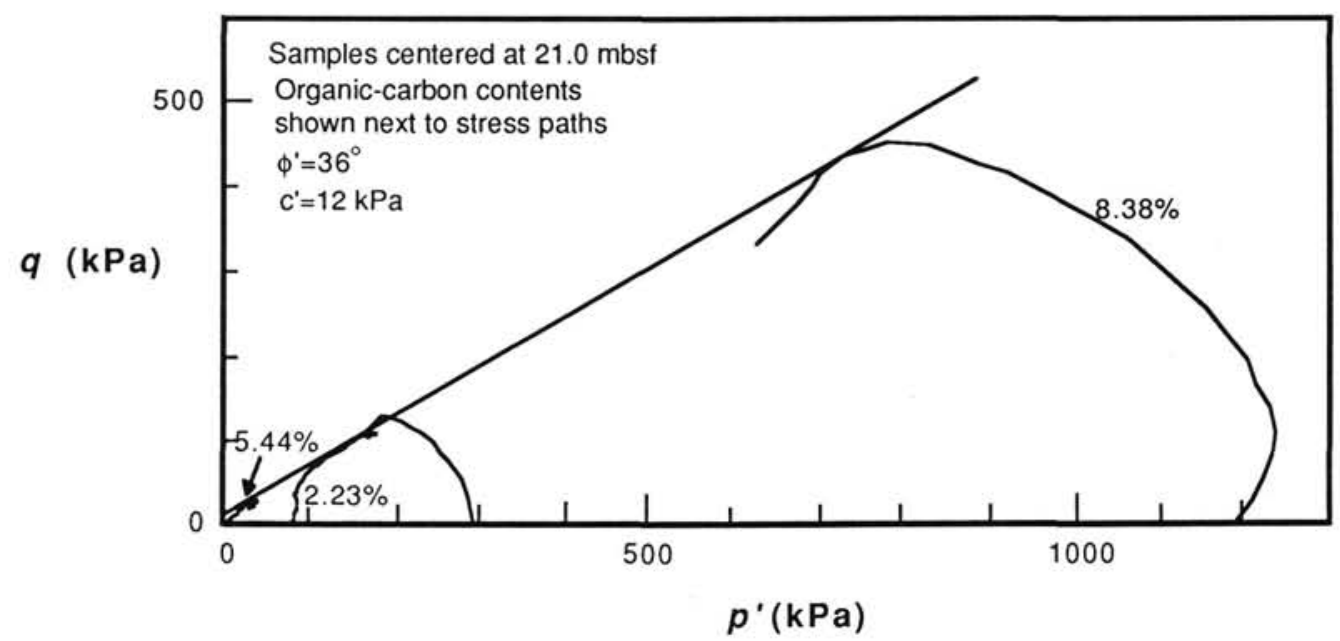

Figure 9. Stress paths (plots of shear stress, $q$, vs. normal effective confining stress, $p^{\prime}$ ) for Hole $680 \mathrm{C}$. Path tendencies to the left indicate contractive sediment behavior; path tendencies to the right indicate dilative behavior. Failure envelopes shown were used to calculate values of friction angle, $\phi$, and cohesion intercept, $c^{\prime}$.

two distributions of normally consolidated shear strength for each site and were developed for Holes 679B, 679D, 680A, $680 \mathrm{~B}, 681 \mathrm{~A}$, and $681 \mathrm{~B}$, for which detailed profiles of density and overburden effective stress were available from shipboard measurements (Suess, von Huene, et al., 1988). Differences between the two distributions at a particular site indicate minor variations in density distributions within a limited seafloor area. Because the distributions of $S$ at Sites 679 and 681 (including the measured value of $S$ for shallow sediment from Busch and Keller, 1983) show a pronounced peak near 20 $\mathrm{m}$ sub-bottom depth, these estimated normally consolidated profiles show an unusually strong zone or "crust" near $20 \mathrm{~m}$.

Also shown in Figures 12 through 14 are several other measurements or estimates of shear strength. All shipboard vane-shear-strength measurements from replicate holes (Suess, von Huene, et al., 1988) are shown; these measurements typically have values greater than the normally consolidated profiles. Results of Type 2 triaxial tests (consolidation to the in-situ overburden effective stress) and shear strengths estimated using the SHANSEP method (Eq. 1, using values of maximum past stress from the consolidation tests and values of $S$ from Fig. 7) roughly agree with each other and follow the trends of the vane-shear test results. Results of Type 1 triaxial tests (consolidation to the residual effective stress) lie well below all other measurements and estimates of shear strength, as expected because of disturbance effects.

\section{DISCUSSION}

\section{Index Properties}

Results of this study (Table 1, Figs. 2 through 4) were compared with a controlled study of organic-carbon content conducted by Booth and Dahl (1986) for sediment from the Santa Barbara Basin and a study of the Peru-Chile continental margin sediment by Busch and Keller (1981). Each study shows general trends of increasing liquid limit, plastic limit, and plasticity and decreasing grain specific gravity with increasing organic-carbon content; however, rates of change differ (Fig. 15).

The trends observed by Busch and Keller (1981) and Booth and Dahl (1986) are roughly parallel, although the latter study shows lower liquid and plastic limit values for equivalent values of organic-carbon content. For these studies, on aver- age, liquid limit increases about $10 \%$ and plastic limit increases about $5 \%$ for a $1 \%$ increase in organic carbon. The rates of increase measured in our study are higher by a factor of about two for the liquid limit and nearly three for the plastic limit. Differences in rates of increase of Atterberg limits with organic-carbon content might be expected between our study and that of Booth and Dahl (1986), given the differences in sample location, preparation, and study objectives. Surprisingly, our results also diverge strongly from those of Busch and Keller (1981), which were obtained from near the surface of the same coastal upwelling facies. Perhaps, changes in sub-bottom depth, in oxidation-reduction potential, rate and extent of organic matter decomposition, and diatom content are important controls on the physical properties of this sediment.

\section{Consolidation and Triaxial Strength Properties}

Figures 12 through 14 summarize the shear-strength measurements and estimates made in our study. Shear strength values obtained by vane shear testing, the SHANSEP method, and by Type 2 triaxial tests are about equal for the same sub-bottom depth. Such consistency among test results probably indicates that these core samples are relatively undisturbed, as might be expected for samples recovered using the hydraulic piston corer. The vane shear measurements are widely scattered, which probably indicates smallscale variations in sedimentologic, geochemical, or disturbance factors. Values obtained using Type 1 triaxial testing are consistently lower than those obtained by other methods and are probably not representative of in-situ conditions.

The vane, Type 2 triaxial, and SHANSEP shear-strength values generally lie well above the shear strengths that might be expected if the sediment were normally consolidated (Figs. 12 to 14). Such a finding suggests that this sediment is apparently overconsolidated and is consistent with consolidation test results, which showed varying degrees of apparent overconsolidation. As discussed previously, the lack of a consistent variation of the excess maximum past stress with sub-bottom depth suggests that overconsolidation was not caused by sediment erosion or slumping. The good correlation between the excess maximum past stress and organic-carbon content (Fig. 5) confirms that geochemical factors control the consolidation state. This overconsolidation is apparent, not 


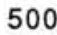

0
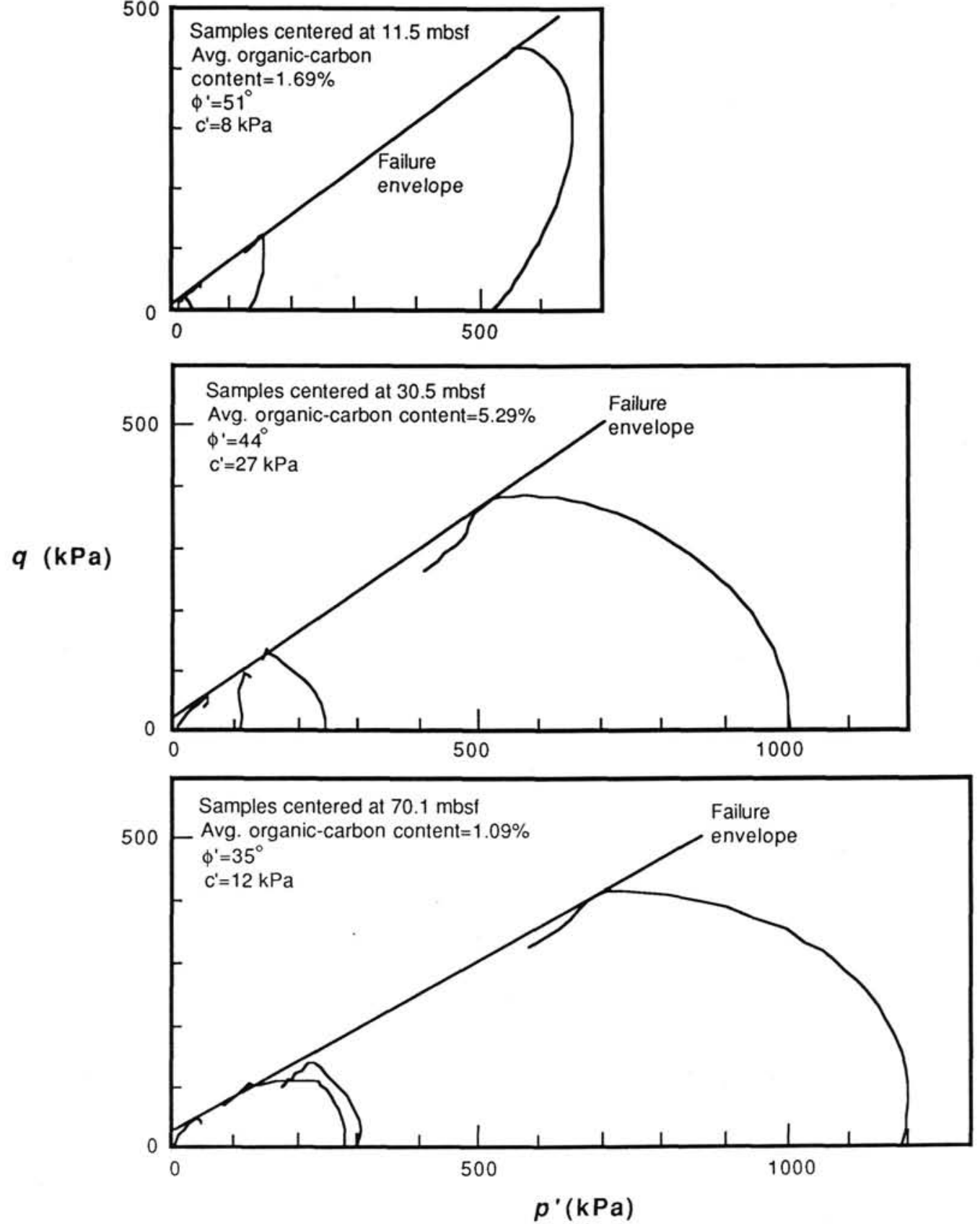

Figure 10. Stress paths (plots of shear stress, $q$, vs. normal effective confining stress, $p^{\prime}$ ) for Hole 681C. Path tendencies to the left indicate contractive sediment behavior; path tendencies to the right indicate dilative behavior. Failure envelopes shown were used to calculate values of friction angle, $\phi^{\prime}$, and cohesion intercept, $c^{\prime}$.

true. Equation 1, the fundamental relationship for the SHANSEP method of estimating sediment shear strength, implies that shear strength may be considered a product of two factors: the shear strength that might exist were the sediment normally consolidated $\left(\sigma_{v}{ }^{\prime} S\right)$ and a strength increase factor $\left(O C R^{m}\right)$ that results if the sediment is overconsolidated. This relationship probably does not apply exactly to sediment that exhibits apparent overconsolidation (Ladd and Foott, 1974) because a value for $m$ is difficult to measure directly under these circumstances. However, if we assume that $m$ still equals about 0.8 for apparent overconsolidation, we can investigate factors causing shear strength development individually, rather than simply appraising the gross measured shear strength. The similarity among vane shear, Type 2 triaxial, and SHANSEP strength values in Figures 12 through 14 shows that the SHANSEP approach of separating strength into factors may be valid.

SHANSEP analysis shows that the high shear strengths at Sites 679,680 , and 681 result from high values of both $S$ and $O C R$. The overconsolidation factor may be a geochemical effect, given the correlation between $\sigma_{e}{ }^{\prime}$ and organic-carbon content (Fig. 5). Values of $S$ correlate with sub-bottom depth. The highest values occur near a depth of about $20 \mathrm{~m}$ and reflect high friction (Fig. 11) and a high degree of dilatancy (Figs. 8 through 10). High friction and dilatancy suggest either interlocking particles (probably the irregularly shaped dia- 


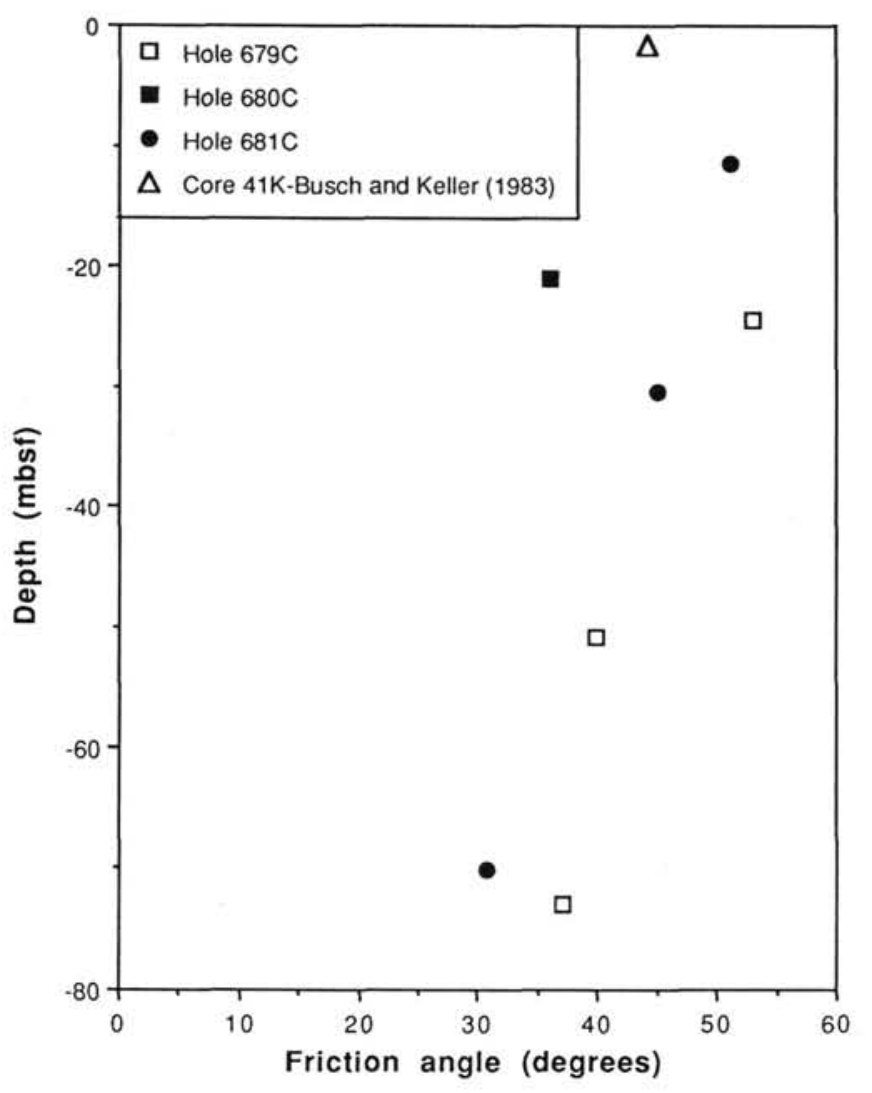

Figure 11. Variation of friction angle, $\phi^{\prime}$ with burial depth.

toms) or a bimodal fabric of organic-mineral aggregates separated by large open pores (Reimers, 1982). Within a bimodal fabric, shear surfaces at low confinement should pass between aggregates and provide little shear resistance. At greater confinement, water from within the space separating aggregates should be expelled, aggregates should be pressed together, and shear surfaces forced to pass through the aggregates rather than between them. Shear strength should increase rapidly with confining stress and friction should seem large.

The organic-mineral aggregate model suggests a failure envelope that curves downward with increasing confining stress. At low stress levels, small increases in confining stress should cause shear planes to be transferred readily from passing through the spaces between aggregates to passing through the aggregates themselves. Such a response should be reflected by particularly high friction. Once the intra-aggregate pore space is exhausted, the aggregates themselves must be consolidated for continued strength increase. Fairly large increases in confining stress might be required for any significant reduction in intra-aggregate pore space because the aggregates must be compact initially to produce the high observed shear strength. Accordingly, the frictional character should be less significant at high stress. High friction angles at low stress levels and low friction angles at high stress levels might be expected. Stress paths of Figures 8 through 10 depict remarkably straight failure envelopes (high friction at both low and high stress levels) for all of the sediment increments tested and thus argue against the organic-mineral aggregate model for the high increases in strength. Grain interlocking might easily lead to straight, high friction angle failure envelopes and is a favored explanation for the high rates of strength increase.

The variation of $S$ and $\phi^{\prime}$ with sub-bottom depth (Figs. 7 and 11) is unusual and cannot be explained by the changes in

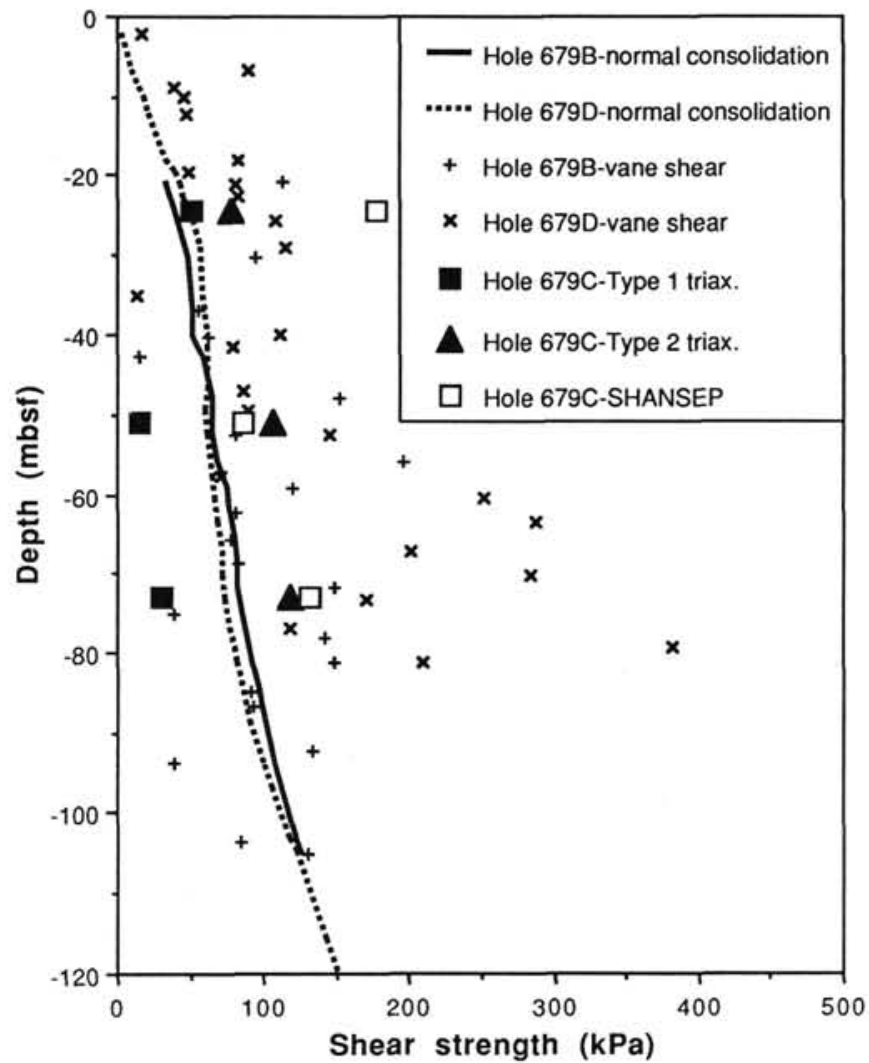

Figure 12. Variation of vane shear strength, estimated normally consolidated shear strength, Type 1 triaxial shear strength (consolidation to the residual effective stress state), Type 2 triaxial shear strength (consolidation to the in-situ overburden effective stress), and shear strength estimated using the SHANSEP method (Eq. 1) for Site 679.

effective confining stress that occur with increasing burial. Because failure envelopes are straight and stress paths within a given section have the same shape, $S$ and $\phi^{\prime}$ are independent of short-term changes in confining stress, such as can be applied in the triaxial cell. There must be other changes occurring in the field with increasing burial depth to cause these parameters to vary; examples include lithologic, diagenetic, or grain shape changes. The lithology of these cores is dominated by diatoms and organic material, which in turn correlate with each other (Fig. 16). The apparent overconsolidation may result from variation in the organic fraction (Fig. 5 ), which may in turn relate to changes in diatom content. However, neither organic-carbon content nor degree of overconsolidation vary consistently with burial depth and accordingly, probably do not cause the observed "crustlike" variation of $S$ and $\phi^{\prime}$. Diagenetic changes, particularly dolomitization (Baker and Burns, 1985) and microbial sulfate reduction (Reimers, 1982), could cause these rapid increases in $S$ and $\phi^{\prime}$ in the upper $20 \mathrm{~m}$, as well as the observed rapid increases in vane shear strength and maximum past stress observed in the upper $2 \mathrm{~m}$ by Busch and Keller $(1981,1982)$. The gradual decrease in $S$ and $\phi^{\prime}$ below $20 \mathrm{~m}$ may also be related to these diagenetic processes, although both increases and decreases in strength being caused by the same factor seems unlikely. A preferred explanation is a gradual chemical and physical breakdown of the diatoms so that they become progressively less able to interlock and develop high friction and dilatancy. However, without a detailed fabric analyses, one cannot draw a firm conclusion regarding the causes of these unusually high strengths or the unusual strength-burial depth variations. 


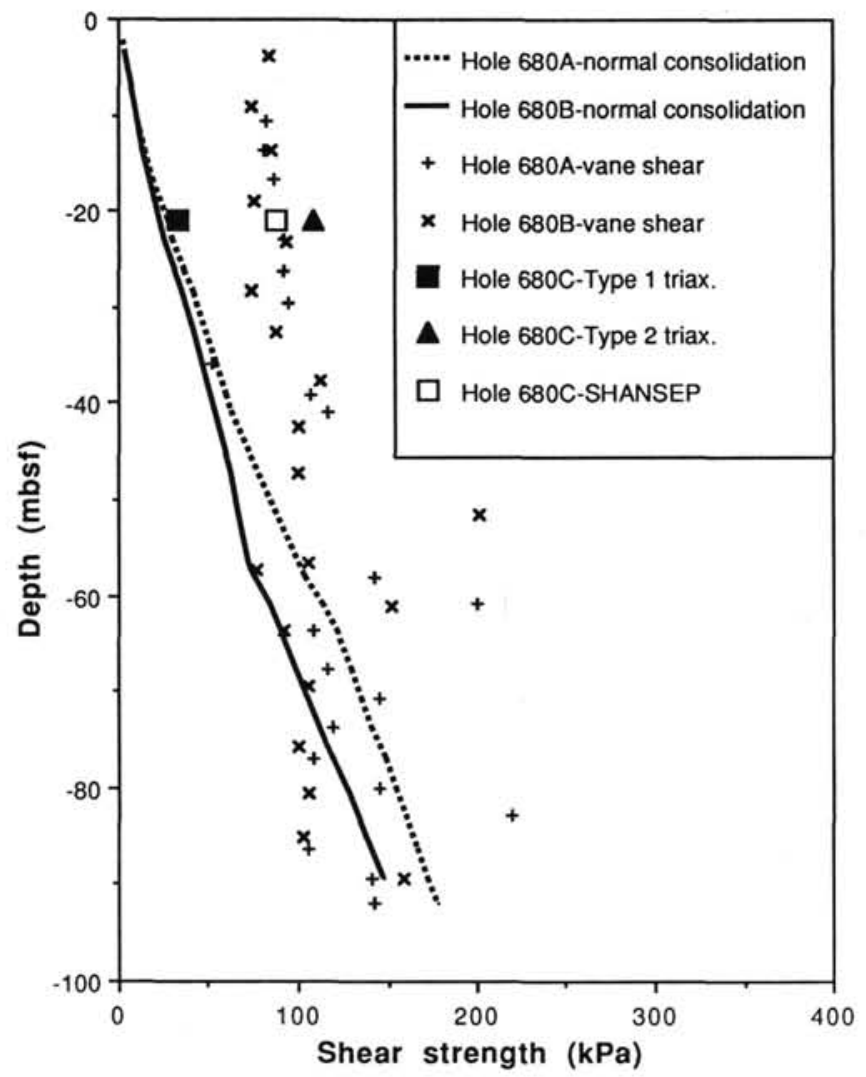

Figure 13. Variation of vane shear strength, estimated normally consolidated shear strength, Type 1 triaxial shear strength (consolidation to the residual effective stress state), Type 2 triaxial shear strength (consolidation to the in-situ overburden effective stress), and shear strength estimated using the SHANSEP method (Eq. 1) for Site 680 .

\section{CONCLUSIONS}

As shown by Busch and Keller $(1981,1982,1983)$, Keller $(1982,1983)$, and confirmed by this study, the sediment within the organic-rich coastal upwelling facies along the Peru continental margin has particularly high water content, Atterberg limits, degree of overconsolidation, compressibility, and shear strength. In addition, this sediment has low density and low grain specific gravity. The Atterberg limits, grain specific gravity, and compressibility of sediment tested from Leg 112 correlate linearly with organic-carbon content. Busch and Keller (1981) also reported similar linear correlations, but these properties were not so strongly dependent. For example, our Atterberg limits increased two to three times as rapidly, relative to organic-carbon content, as did the Atterberg limits of Busch and Keller. The difference between the studies probably lies in the sub-bottom depth range tested. Busch and Keller tested sediment from the upper $4 \mathrm{~m}$ of the sediment column, whereas we tested sediment from burial depths of 10 to $75 \mathrm{~m}$. Changes with depth of oxidationreduction potential, extent of organic material decomposition, and, in particular, diatom content could have caused the differences in correlations between shallow and deep sediment. The Leg 112 sediment tested shows a strong direct relationship between organic-carbon content and diatom content (Fig. 16). Because diatoms also typically lead to high values of Atterberg limits and water content and low values of grain specific gravity, changes in organic-carbon content in the Leg 112 samples can have an amplified influence on

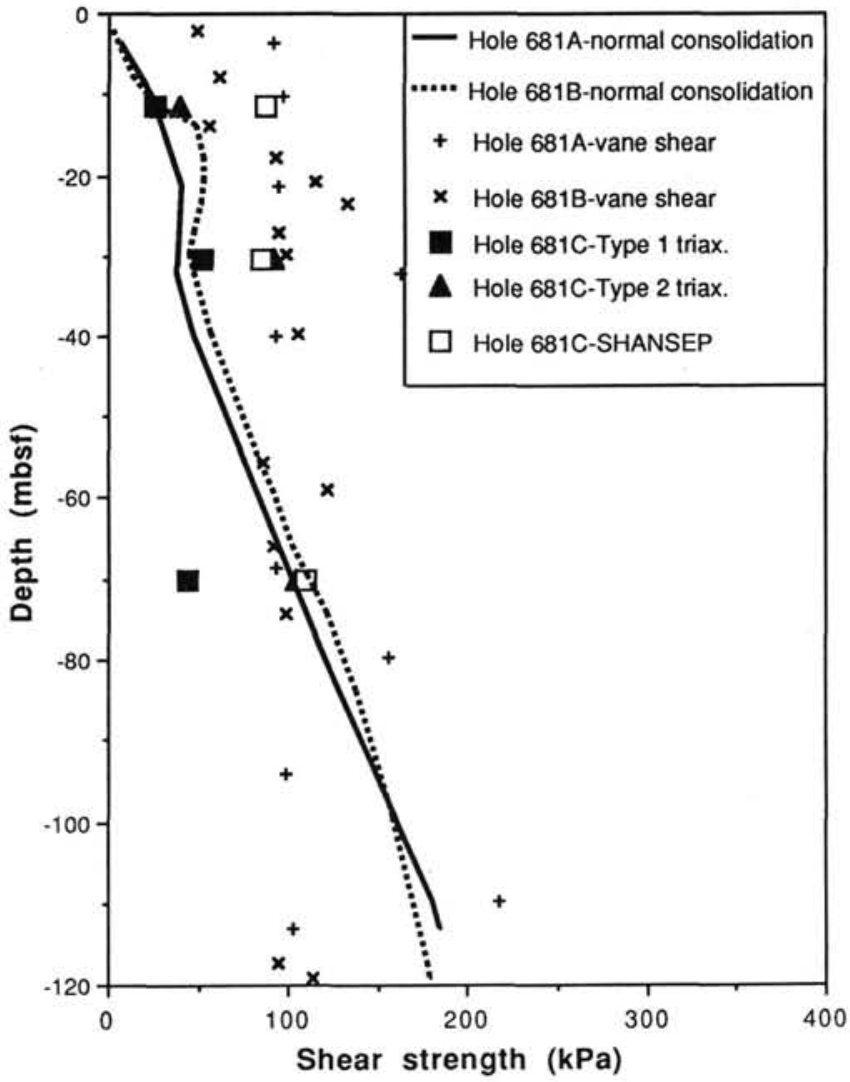

Figure 14. Variation of vane shear strength, estimated normally consolidated shear strength, Type 1 triaxial shear strength (consolidation to the residual effective stress state), Type 2 triaxial shear strength (consolidation to the in-situ overburden effective stress), and shear strength estimated using the SHANSEP method (Eq. 1) for Site 681 .

physical properties through corresponding changes in diatom content.

Three testing techniques yielded about the same shear strength distributions with depth at Sites 679,680 , and 681 . These techniques are (1) shipboard vane shear testing, (2) triaxial testing in which samples were initially consolidated to the level of the in-situ overburden stress (test Type 2), and (3) strengths estimated using SHANSEP, a method that presents shear strength as a product of normalized factors. In the absence of any in-situ testing, and considering that the samples were recovered with a high-quality corer, any one of these strength results may be considered a good measure of in-situ behavior. The SHANSEP method yields the most informative results because individual factors influencing strength, as well as the total shear strength, can be evaluated. The overconsolidated behavior suggested in these tests is only an apparent overconsolidation; that is, not a result of sediment erosion, but the result of diagenetic or other interparticle bonding factors. The amount of apparent overconsolidation correlates with the organic-carbon content, suggesting interparticle organic bonding. The rate $(S)$ at which strength increases with overburden stress for normally consolidated sediment increases rapidly with burial depth until a peak value is reached near $20 \mathrm{~m}$. At greater depths, $S$ declines to about 0.35 , a value typical of many other types of marine sediment. The changes in $S$ reflect corresponding changes in friction angle and relative dilatancy during shear. This crustlike behavior is probably produced by early diagenesis within the 


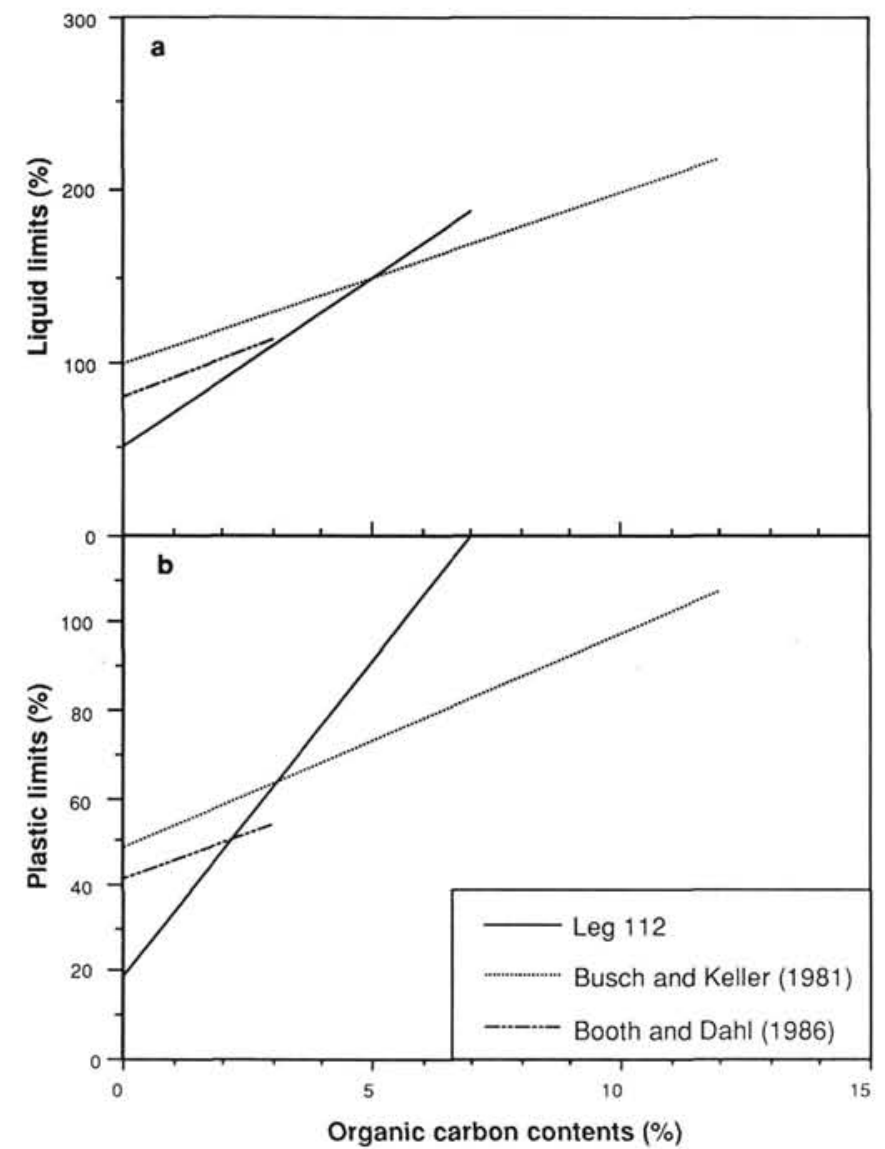

Figure 15. Comparison of regression lines relating (a) liquid limit and (b) plastic limit to organic-carbon contents for Leg 112 sediment and previously published studies.

upper $20 \mathrm{~m}$, and is complemented by interlocking of diatoms. Lower values of $S$ below $20 \mathrm{~m}$ suggest a breakdown in the diatom particles, so that they are progressively less able to interlock and develop frictional resistance.

High shear strengths and distinctive shear strength profiles within an organic-rich facies appear to reflect a complex interplay of diagenetic and frictional factors. These high strengths are probably related to the high values of organiccarbon content, but may also reflect other factors that cannot be quantified at present.

\section{ACKNOWLEDGMENTS}

The authors thank Janice Marsters for shipboard processing and preservation of core samples. Helpful reviews of this manuscript were provided by Monty Hampton, Philip Hill, Elliott Taylor, and William Winters.

\section{REFERENCES}

American Society for Testing and Materials, 1982. Annual Book of ASTM Standards, Part 19, Soil and Rock; Building Stones: Philadelphia (ASTM).

Andersland, O. B., Khattak, A. S, and Al-Khafaji, A.W.N., 1981. Effect of organic material on soil shear strength. In Yong, R. N., and Townsend, R. C., (Eds.), Laboratory Shear Testing of Soil. Am. Soc. Testing and Materials, STP 740:226-242.
Baker, P. A., and Burns, S. J., 1985. Occurrence and formation of dolomite in organic-rich continental margin sediments. $A A P G$ Bull., 69:1917-1930.

Bishop, A. W., and Henkel, D. J., 1957. The Measurement of Soil Properties in the Triaxial Test: London (Edward Arnold, Ltd.).

Booth, J. S., and Dahl, A. G., 1986. A note on the relationships between organic matter and some geotechnical properties of a marine sediment. Mar. Geotechnol., 6:281-297.

Busch, W. H., and Keller, G. H., 1981. The physical properties of Peru-Chile continental margin sediments-the influence of coastal upwelling on sediment properties. J. Sediment. Petrol., 51:705719.

1982. Consolidation characteristics of sediments from the Peru-Chile continental margin and implications for past sediment instability. Mar. Geol., 15:17-39.

1983. Analysis of sediment instability on the Peru-Chile continental slope. Mar. Geotechnol., 5:181-211.

Casagrande, A., 1936. The determination of the pre-consolidation load and its practical significance. Proc., First Int. Conf. Soil Mech. Found. Engineering, 3:60-64.

1948. Classification and identification of soils. Trans. Am. Soc. Civil Engrs., 113:901.

Keller, G. H., 1969. Engineering properties of some seafloor deposits. J. Soil Mech. Found. Div. (ASCE), 95:1379-1392.

1982. Organic matter and the geotechnical properties of submarine sediments. Geo-Mar. Lett., 2:191-198.

1983. Coastal upwelling, its influence on the geotechnical properties and stability characteristics of submarine deposits. In Thiede, J., and Suess, E. (Eds.), Coastal Upwelling, its Sediment Record, Part B: New York (Plenum Press), 181-198.

Ladd, C. C., and Foott, R., 1974. New design procedure for stability of soft clays. J. Geotech. Engrg. (ASCE), 100:763-786.

Ladd, C. C., Foott, R., Ishihara, K., Schlosser, F., and Poulos, H. G., 1977. Stress deformation and strength characteristics. Proc. 9th Int. Conf. Soil Mech. Found. Engrg., Tokyo, 2:421-494.

Lambe, T. W., 1951. Soil Testing for Engineers: New York (Wiley).

Lambe, T. W., and Whitman, R. V., 1969. Soil Mechanics: New York (Wiley).

Lee, H. J., 1979. Offshore soil sampling and geotechnical parameter determination. Proc., 11th Offshore Tech. Conf., Houston, 14491453.

Mayne, P., 1980. Cam-clay prediction of undrained strength. J. Soil Mech. Found. Div. (ASCE), 106:1219-1242.

Pusch, R., 1973. Influence of Organic Matter on the Geotechnical Properties of Clays (National Swedish Building Research Document 11).

Rashid, M. A., and Brown, J. D., 1975. Influence of marine organic compounds on the engineering properties of a remolded sediment. Engrg. Geol., 9:141-154.

Reimers, M. A., 1982. Organic matter in anoxic sediments off central Peru: relations of porosity, microbial decomposition, and deformation. Mar. Geol., 46:175-192.

Reimers, C. E., and Suess, E., 1983. Spatial and temporal patterns of organic matter accumulation on the Peru continental margin. In Thiede, J., and Suess, E. (Eds.), Coastal Upwelling: Its Sediment Record, Part B: New York (Plenum Press), 311-337.

Richards, A. F., and Hamilton, E. L., 1967. Investigations of deepsea sediment cores, III. Consolidation. In Richards, A. F. (Ed.), Marine Geotechnique: Carbondale (Univ. of Illinois Press), 93117.

Suess, E., von Huene, R., et al., 1988. Proc. ODP, Init. Repts., 112: College Station, TX (Ocean Drilling Program).

Wissa, A.E.Z., Christian, J. T., Davis, E. H., and Heiberg, S., 1971. Consolidation at constant rate of strain. J. Soil Mech. Found. Div. (ASCE), 97:1393-1413.

Date of initial receipt: 21 November 1988

Date of acceptance: 8 May 1989

Ms 112B-169 


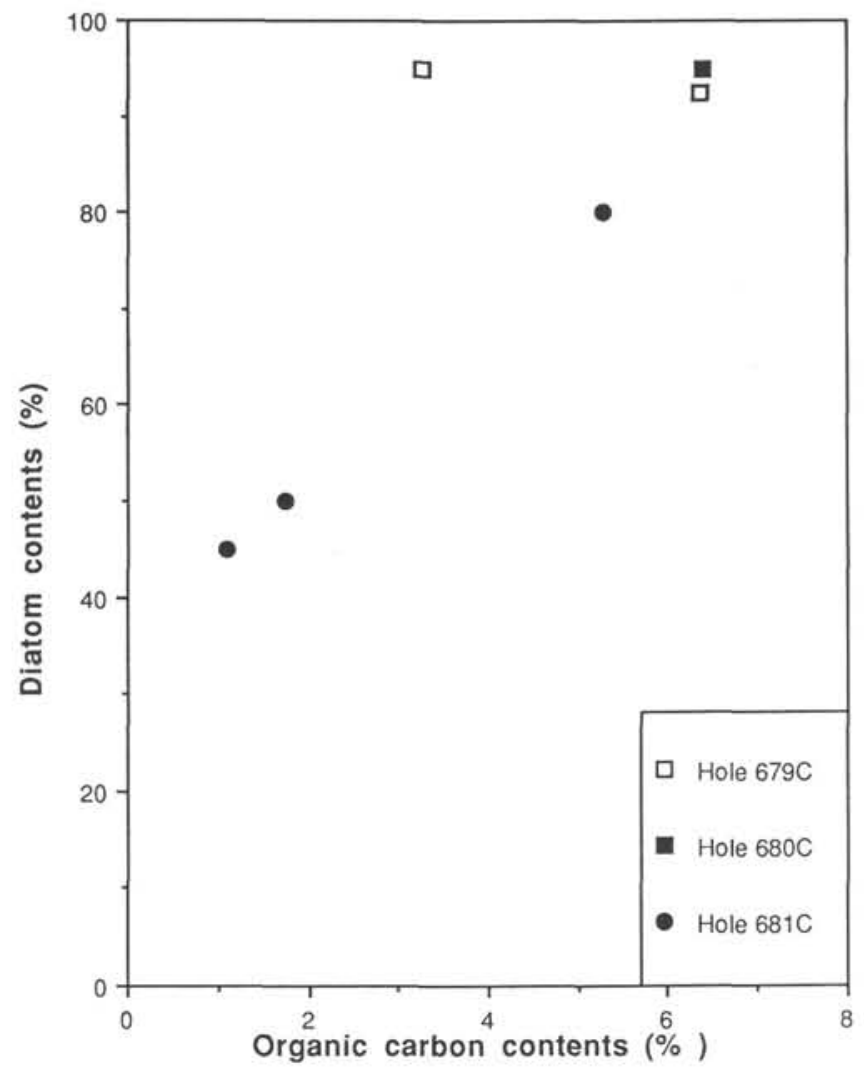

Figure 16. Relationship of diatom contents to organic-carbon contents. Content of diatom is approximate and was obtained from visual assessment of smear slides. 